\title{
Aqua Tower w Chicago \\ - nieenergooszczędny ekologiczny wieżowiec (ikona modernistycznej architektury)
}

\author{
Jerzy Szołomicki, Piotr Berkowski \\ Zaktad Fizyki Budowli i Komputerowych Metod Projektowania, \\ Wydziat Budownictwa Ladowego i Wodnego, Politechnika Wroctawska, \\ e-mail: jerzy.szolomicki@pwr.edu.pl,piotr.berkowski@pwr.edu.pl
}

Streszczenie: W artykule przedstawiono elementy analizy architektonicznej i konstrukcyjnej „ekologicznego” wieżowca Aqua Tower w Chicago - ikony architektury modernistycznej. Myślą przewodnią opracowania koncepcji budynku Aqua Tower było stworzenie budynku ekologicznego o oryginalnej formie, pełniącego funkcję hotelowo-mieszkalną. Chicagowski wieżowiec został wyposażony w nieregularnie rozmieszczone balkony, tworzące ,powłokę” pokrywającą prostopadłościenną bryłę główną. Zaprojektowany kształt budynku znacząco zmniejsza jego podatność i niedostateczne tłumienie drgań, spowodowane oddziaływaniem wiatru, które jest charakterystyczne dla budynków wysokich. W części pierwszej artykułu przeanalizowano różne formy geometryczne współczesnych budynków wysokich. Następnie scharakteryzowano wieżowiec Aqua Tower pod względem architektonicznym i konstrukcyjnym, biorąc pod uwagę oddziaływanie wiatru oraz aspekt ekologiczno-energooszczędny. Budynek Aqua Tower jest zadziwiającym dziełem, pokazującym jak można kreatywnie zastosować beton, żeby uzyskać wybitną architekturę i wytrzymałą konstrukcję. W wieżowcu wykorzystano cały zestaw proekologicznych rozwiązań, do których należą między innymi system magazynowania wody deszczowej oraz energooszczędne oświetlenie. Roślinność umieszczona pomiędzy wyraźnie zaznaczonymi poziomymi podziałami elewacyjnymi sprawia wrażenie silnego sprzężenia tak kontrastujących ze sobą betonu i zieleni. Roślinny taras dachowy na trójkondygnacyjnym podium tworzy obraz „geometrycznego naturalizmu”, który nie tylko daje efekt estetyczny, ale także pozwala obniżyć temperaturę otoczenia.

Słowa kluczowe: Aqua Tower; budynki wysokie; formy geometryczne; ekologia.

\section{Wprowadzenie}

Miejscem narodzin wieżowca, wykształconego jako nowa forma budynku, były Stany Zjednoczone. Wieżowce doskonale pasowały do urbanistyki i topografii amerykańskich miast, rozplanowanych zazwyczaj jako obszary, oparte na regularnej ortogonalnej sieci ulic [1]. Pierwsze budynki wysokie zostały wzniesiono w Chicago na początku XIX w. Cechowała je bardzo prosta forma, bez dekoracji, urozmaicona jedynie wykuszami. Zjawisko to było charakterystyczne dla projektowania obiektów o skali i funkcji, dla których odniesienia historyczne nie istnieją. Szybka ewolucja formy architektonicznej oraz towarzyszących jej systemów konstrukcyjnych nastąpiła od czasu pożaru w Chicago w 1871 roku. „Szkoła chicagowska" to nurt w architekturze powstały na przełomie XIX i XX wieku, który uważa się za wstęp do modernizmu i budownictwa wysokiego. Głównymi przedstawicielami tej 
szkoły byli Dankmar Adler i Louis Sullivan, którzy opracowali konstrukcje pozwalające budować budynki wyższe niż do tej pory (World Columbian Exposition 1893 (85 m), Chicago Stock Exchange 1893-1894 (57 m), Auditorium Building 1887-1889 (73 m)).

W 1934 roku do Chicago przyjechali założyciele szkoły Bauhaus, Walter Gropius i Ludwik Mies van de Rohe, którzy zapoczątkowali tzw. „drugą szkołę chicagowską”. Do historii architektury przeszły budynki zaprojektowane przez Van de Rohe, które dziś uważane są za ikony współczesnej architektury. Należą do nich 26-piętrowe apartamentowce przy Lake Shore Drive (1949) w Chicago oraz 38-piętrowy Seagram Building w Nowym Jorku (1958). Oba te projekty doskonale realizują idee Bauhausu: prostopadłościenny kształt, stalowy szkielet i całkowicie przeszklone ściany.

Na początku ery wysokościowców budowle wysokie powstawały w Chicago (John Hancock Center (1969), Aon Center (1973), Willis Tower (1974)) i w Nowym Jorku (Chrysler Building (1930), Rockeffeler Center (1933), (World Trade Center 1 i 2 $(1970,1971))$ i to tam została zapoczątkowana rywalizacja o posiadanie najwyższego budynku na świecie. Jednym z najciekawszych przykładów tej rywalizacji jest wybudowany w 1931 roku w Nowym Jorku Empire State Building (381 m), który przez ponad 40 lat był najwyższym budynkiem świata, do momentu, w którym ukończono dwie wieże World Trade Center (WTC1 417 m, WTC2 415 m.). Wówczas to one stały się centralnymi punktami nowojorskiej architektury. 11 września 2001 roku wieże zostały zniszczone przez atak terrorystyczny. W ich miejsce powstał nowy wieżowiec One World Trade Center $(541 \mathrm{~m})$, autorstwa Daniela Libeskinda i Davida Childsem'a (Skidmore, Owings\&Meril).

W latach 90-tych XX wieku nastąpił gwałtowny rozwój budownictwa w Azji, który zapoczątkował ogromną aktywność w budowaniu wieżowców. Znaczną rolę w tym procesie odegrały Chiny i Zjednoczone Emiraty Arabskie. W latach 30-tych 99\% ze 100 najwyższych budynków na świecie było zlokalizowanych w Ameryce Północnej, natomiast w 2010 ten procent spadł do $22 \%$ [2].

Pierwsze miejsce w rankingu najwyższych budynków świata przypada od 2010 roku wieżowcowi Burj Khalifa, zlokalizowanemu w Dubaju w Zjednoczonych Emiratach Arabskich (829 m; Adrian Smith, Skidmore, Owings\&Merill). Jednak od kilka lat w Arabii Saudyjskiej przygotowywany jest jeszcze bardziej spektakularny projekt i przedsięwzięcie. Jest nim budowa Kingdom Tower, której wysokość po raz pierwszy w historii przekroczy barierę $1000 \mathrm{~m}$.

Budynki wysokie na samym początku były w 90\% przeznaczone na biura przedsiębiorstw i w $10 \%$ na hotele. Istotna zmiana nastąpiła w latach 90-tych, kiedy wzrosła liczba obiektów wielofunkcyjnych, łączących funkcje mieszkalne, biurowe i hotelowe.

Rozwój budynków wysokich nierozerwalnie wiąże się z poszukiwaniem wydajnych materiałów konstrukcyjnych, pozwalających budować wyżej, szybciej i bezpieczniej. Początkowo prym w konstrukcjach budynków wysokich wiodła stal, jako że technologia betonu była nie dość rozwinięta, a produkowane betony cechowała znacznie niższa wytrzymałość niż stal. Obecnie można dostrzec coraz większe zainteresowanie betonem jako głównym materiałem konstrukcyjnym w tego typu obiektach. Na przestrzeni ostatnich lat nastąpił także znaczny postęp w dziedzinie modelowania właściwości fizycznych i reologicznych betonu. Dodawane domieszki umożliwiają znaczny wzrost wytrzymałości, przyspieszają okres dojrzewanie betonu i umożliwiają wykonywanie prac budowlanych w temperaturach zarówno bardzo niskich, jak i bardzo wysokich. Współczesne betony ultrawysokowartościowe (UBPC) odznaczają się wytrzymałością większą od $150 \mathrm{MPa}$. Również rozwój technologii budowy (szalunki przestawne o dużej dokładności i szybkości montażu i demontażu, systemy transportu pionowego - pompy, itp.), duża podatność na 
kształtowanie, szybszy wzrost wytrzymałości niż ceny, duża odporność ogniowa - to kolejne zalety przemawiające za stosowaniem betonu.

Rozwój technologii betonu i metod organizacji budowy pozwolił nie tylko na wznoszenie coraz wyższych wieżowców, ale także na urozmaicanie ich formy i kształtów. Rozwijają się również technologie mieszane, stalowo-betonowe, czego przykładem mogą być Petronas Twin Tower w Kuala Lumpur (1998, 452 m (Rys. 1a)), Burji Khalifa (2010, 829 m (Rys. 1b)), Princess Tower (2012, 413 m (Rys. 1c), One57 (2014, 306 m (Rys. 1d), Kingdom Center (2002, 302 m (Rys. 1e)). Obecnie wśród 100 najwyższych budynków świata 10 wybudowanych jest jako konstrukcje stalowe, 34 - jako żelbetowe, 5 - jako stalowo-żelbetowe, a 51 - jako kompozytowe zespolone [3].

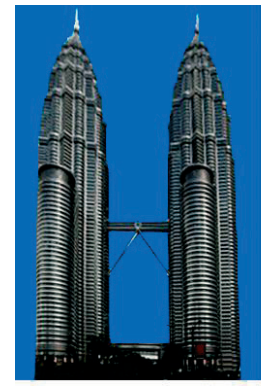

a)

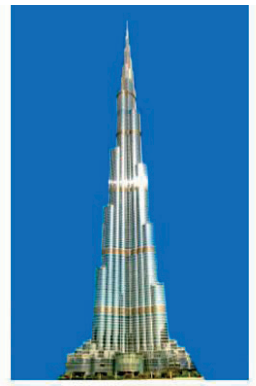

b)

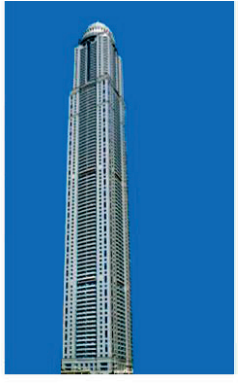

c)

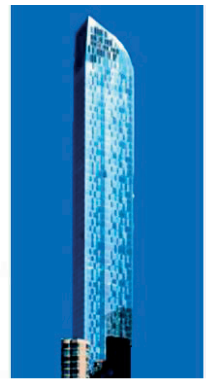

d)

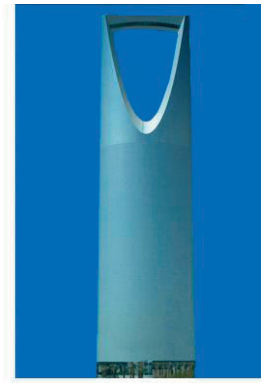

e)

Rys. 1. (a) Petronas Twin Towers, Kuala Lumpur (Cesar Pelli); (b) Burji Khalifa, Dubaj (Adrian Smith, Skidmore, Owings\&Merrill); (c) Princess Tower, Dubaj (Adnan Saffarini Office); (d) One57, Nowy Jork (Christian de Portzamparc); (e) Kingdom Center, Rijad (Ellerbe Becket Omrania\&Associates)) (Opracował J. Szołomicki)

Projektowanie budynków wysokich o skomplikowanych formach ułatwił także rozwój technologii komputerowych. Większa moc obliczeniowa komputerów pozwoliła na tworzenie bardziej zaawansowanych programów inżynierskich, które umożliwiają budowanie modeli coraz lepiej odwzorowujących rzeczywiste zachowanie konstrukcji. Widać to szczególnie w budynkach wysokich $\mathrm{z}$ ostatnich dwudziestu lat. Współczesne projekty burzą stereotypy wysokościowców i zaskakują skomplikowanymi formami nawiązującymi do historii, tradycji, a nawet religii. Wieżowce sprzyjają rozwojowi nowatorskich rozwiązań nie tylko w zakresie konstrukcji, ale także w dziedzinach komunikacji pionowej, ograniczenia zużycia energii, poprawienia komfortu przebywania człowieka w budynku czy też bezpieczeństwa przebywających w nim ludzi. Organizacja działania i nowoczesne wyposażenie budynków wysokich sprawia, że zaliczane są one do kategorii „budynków inteligentnych”.

Doskonałym przykładem takiego budynku jest Aqua Tower w Chicago, który jest przedmiotem analizy w dalszej części artykułu. Obecnie Chicago jest nie tylko kolebką wieżowców, ale i miastem o bogatej panoramie architektonicznej. Stoją tutaj obok siebie wieżowce z początku XX wieku ozdobione w stylu secesji i art deco, modernistyczne wieże z połowy ubiegłego stulecia oraz najnowsze realizacje najwybitniejszych architektów świata.

\section{Formy geometryczne budynków wysokich}

Wysokie budynki często były projektowane standardowo, w postaci prostopadłościennej bryły ze szklanymi elewacjami. Budynki takie, choć praktyczne i estetyczne, są w pewnym stopniu monotonne. Współczesna architektura próbuje tej monotonności stawić 
czoła. Oprócz masowej realizacji racjonalnych budynków wysokościowych, opartych o podobne, skodyfikowane już, założenia konstrukcyjne i formalne, odnotować należy pojawienie się w budownictwie wysokościowym innego trendu. Jest to zjawisko wznoszenia budynków ,ikonicznych”, wyróżniających się swoimi kształtami i skalą.

Bryły geometryczne (m.in. wielościany, stożki, walce, kule, elipsoidy, torusy) oraz krzywoliniowe powierzchnie pojawiają się, jako elementy składowe każdego współczesnego wieżowca $[4,5,6]$. Analizując formę obiektu można wyodrębnić konkretne rodzaje podstawowych brył lub powierzchni stosowanych w całości albo w postaci fragmentów. Ponadto do kreowania kompozycji obiektu wykorzystuje się różne rodzaje zniekształceń tych brył lub powierzchni. Generalnie, formy przestrzenne można geometrycznie podzielić na wielościany, bryły obrotowe i powierzchnie.

Z punktu widzenia formy architektonicznej współczesne wieżowce możemy zakwalifikować do następujących grup [7]: extruder, rotor, twister i tordos oraz dowolny kształt.

\section{Extruders}

Budynki tego typu mają na całej wysokości taki sam przekrój poprzeczny. Przykładem może być bryła prostopadłościenna lub cylindryczna (Rys. 2a). W ramach tej grupy mogą występować następujące modyfikacje:

- poszczególne kondygnacje są ułożone jedna na drugiej w stałym nachyleniu, rzuty kondygnacji mogą mieć prosty lub zakrzywiony kontur (,anglers”, Rys. 2b),

- kondygnacje ułożone jedna na drugiej przy różnym kącie nachylenia, często w postaci prostych segmentów pochylających się w różnych kierunkach, płynnie połączonych z wygiętymi segmentami (,sliders”, Rys. 2c), mogącymi ulec przewężeniu wraz ze wzrostem wysokości („tapering sliders”, Rys. 2d). Pojedyncze budynki tego typu mogą być połączone ze sobą w grupach w celu zapewnienia większej sztywności lub zapewnienia wyjścia przeciw pożarowego. (“slider assemblies”, Rys. 2e).

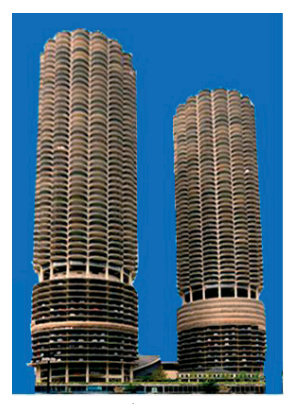

a)

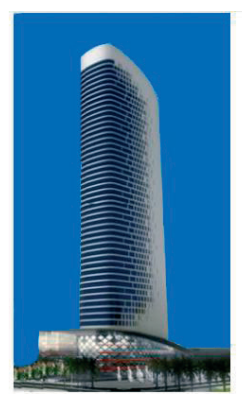

b)

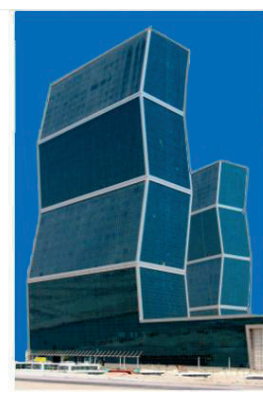

c)

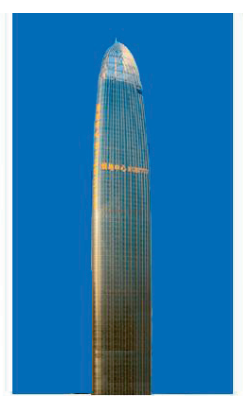

d)

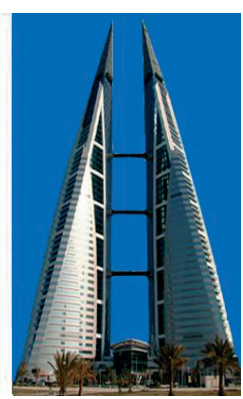

e)

Rys. 2. (a) Marina City towers, Chicago (Bertrand Goldberg); (b) Gate Bay, Dubai (Bothe Richter, Teheran Architects BDA); (c) Zig Zag Towers, Doha (MZ\&Partners); (d) Greenland Puli Center, Jinan (Skidmore, Owings\&Merrill); (e) World Trade Center, Bahrain (Atkins Company) (Opracował J. Szołomicki)

\section{Rotors}

Budynki tej grupy mają formę bryły obrotowej, powstałej w wyniku obrotu figury płaskiej dookoła prostej stanowiącej oś obrotu (Rys. 3c). Gdy oś obrotu jest pochylona wtedy bryła może uzyskać formę hiperboloidy. W wyniku obrotu okręgu dokoła pionowej osi uzyskuje się formę kuli. Model bryły obrotowej budynku może mieć formę wypukłą (,,bulging rotor”, Rys. 3 abcde) lub formę wklęsłą (,squeezed rotor”) w zależności od przyjętej 
krzywej obrotu, której krzywizna może być bardzo złożona (Rys. 3a). Uzyskana forma bryły budynku może mieć również eliptyczny przekrój poprzeczny i wtedy zaliczana jest do typu „transformed rotors” (Rys. 3cde).

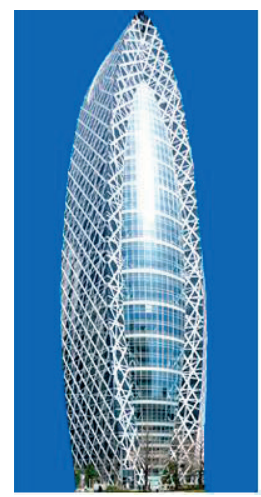

a)

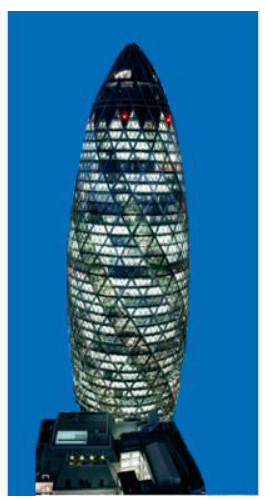

b)

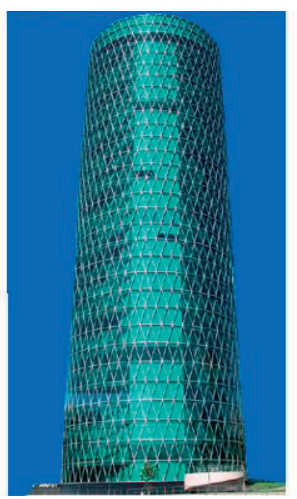

c)

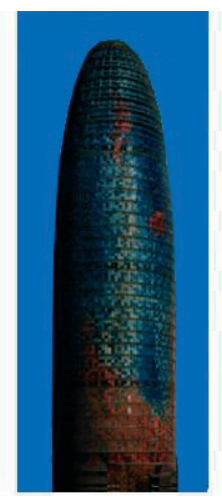

d)

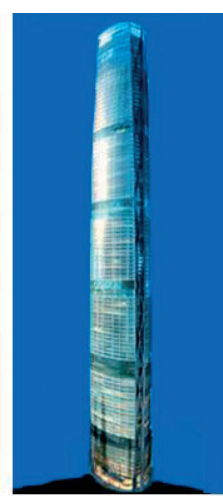

e)

Rys. 3. (a) Mode Gakuen Cocoon Tower, Tokio (Kenzo Tange Associates); (b) Swiss Re, Londyn (Norman Foster\&Partners); (c) Westhafen Tower, Frankfurt (Schneider, Schumacher); (d) Torre Agbar, Barcelona (Jean Nouvel i Fermin Vazquez); (e) International Financial Center, Guangzu (Wilkinson Eyre) (Opracował J. Szołomicki)

\section{Twister i Tordos}

Budynki tego typu mają formę skręconej bryły z fasadą powtarzaną na wszystkich kondygnacjach „twister” (Rys. 4a). Budynki z ortogonalnym trzonem i z jedną lub dwoma skręconymi wieżami należą do kategorii „toros” (Rys. 4b). Inspiracja do przekształcenia osi w Revolution Tower (Rys. 4c) w spiralną formę może pochodzić z inżynierskiej logiki do usytuowania asymetrycznych kondygnacji nie przez środek okrągłego segmentu kondygnacji, ale przez środek ciężkości kondygnacji. Kiedy kondygnacje są przesunięte w górę wzdłuż krzywej 2D lub 3D i dodatkowo dodana jest rotacja do zewnętrznej konstrukcji to bryła budynku należy do kategorii „sliding twister” (Rys. 4c). Gdy krzywa obrotu 3D jest spiralą to należy do kategorii „helical twister” (Rys. 4de). Przecinające się bryły budynku w kształcie skręconych spirali mają wewnętrzną pionową strefę przeznaczoną na szyby windy.

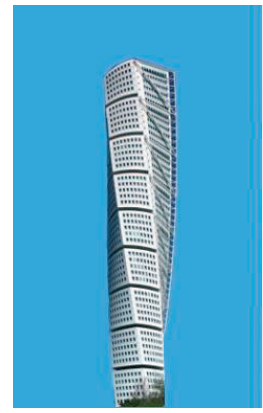

a)

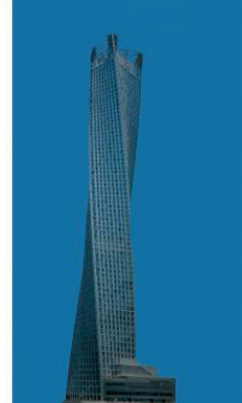

b)

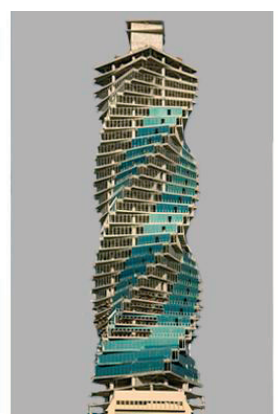

c)

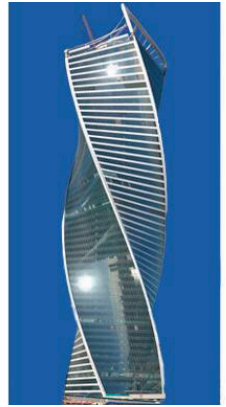

d)

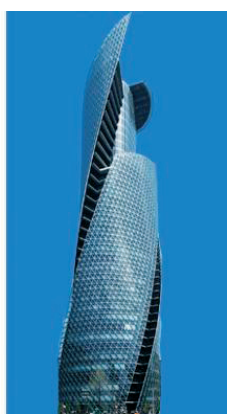

e)

Rys. 4. (a) Turning Torso, Malmö (Santiago Calatrava); (b) Infinity Tower (Cayan), Dubai (Skidemore, Owings and Merrill); (c) Revolution Tower, Panama City (Pinzon Lozano\&Asociados); (d) Evolution Tower, Moskwa (Tony Kettle); (e) Mode Gakuen Spiral Towers, Nagoya (Nikken Sekkei) (Opracował J. Szołomicki) 


\section{Dowolny ksztalt}

Forma budynku o dowolnej geometrii jest wykonana przy zastosowaniu kombinacji geometrycznie prostych obiektów (linia, powierzchnia, bryła), gdy sekwencja działań architekta projektującego formę budynku nie jest oczywista oraz gdy forma nie pasuje do żadnej innej kategorii. W kategorii tej możemy wyróżnić podkategorię „slicers”. Należą do niej budynki, które mają zakrzywioną fasadę poprzez balkony oraz inne wysunięte elementy. Na Rys. 5a zakrzywiona zewnętrzna powierzchnia jest uzyskana przez kontury wijących się balkonów dookoła prostopadłościennej bryły. Alternatywnie zakrzywione segmenty balkonów mogą powtarzać się na wyższych kondygnacjach wraz z ich obrotem (Rys. 5b). To pionowe skręcenie zewnętrznej powierzchni tworzy w przekroju nie linię prostą ale krzywą. Cofnięta fasada w budynku z Rys. 5b jest ozdobiona płaskimi elementami. Gładka powierzchnia budynku na Rys. 5c jest uzyskana poprzez dużą ilość żaluzji. Pionowość balustrad jest mniej oczywista w wieżowcach niż w budynkach niskich (Rys. 5d), gdzie fasada jest raczej schodkowa i nie tworzy wygładzonej krzywej. Gdy budynek ma powtarzające się pionowe kondygnacje wraz z poziomym ich obrotem to jest zaliczany do kategorii „sliced twister” (Rys. 5b).

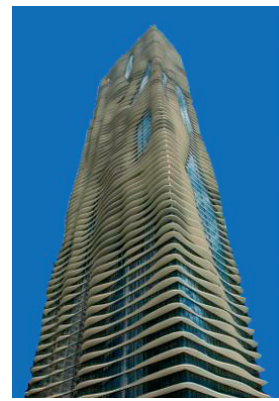

a)

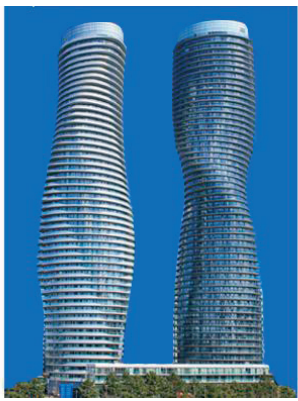

b)

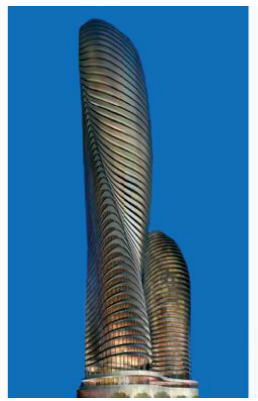

c)

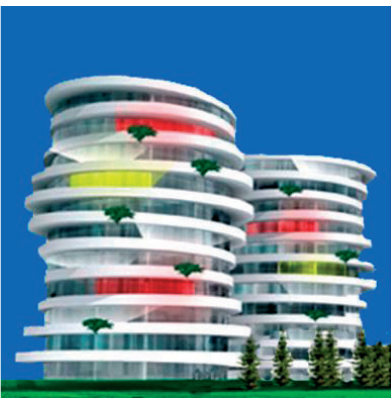

d)

Rys. 5. (a) Aqua Tower, Chicago (Jeanne Gang); (b) Absolute World Buildings, Mississauga Ontario (Burka Architects i Mad Architects); (c) Slinky Twins Towers, Paryż (Philippe Chiambaretta Architecte); (d) Nordhaven Residences, Kopenhaga (3XN team: Kim Herforth Nielsen, Henriette Byrge, Melanie Zirn, Jan Ammundsen) (Opracował J. Szołomicki)

\section{Aqua Tower w Chicago - ikoniczny budynek modernistycznej architektury}

\subsection{Architektura budynku}

Wielu architektów prześciga się w projektowaniu wieżowców o coraz to bardziej urozmaiconych formach. Pojawienie się nowych systemów obliczeniowych spowodowało wzrost zainteresowania projektowaniem „free-form”, a możliwość matematycznego opisania złożonych form ze skomplikowanymi krzywiznami zaowocowała szeregiem eksperymentów architektonicznych, co zresztą jest naturalną konsekwencją pojawienia się każdej nowej technologii.

Powstają więc budynki o prostej bryle, ale z oryginalnymi elewacjami. Jest to zrozumiałe, gdyż oryginalna forma powoduje powstanie rozpoznawalnego adresu i to nie tylko w skali miasta, ale również całego świata. Przykład może stanowić Aqua Tower, wielorodzinny wieżowiec mieszkaniowy zrealizowany według projektu zespołu architektów Studio Gang Architects, kierowanego przez Jeanne Gang [8]. Zbudowany przez Magellan Deve- 
lopment budynek był pierwszym budynkiem wysokościowym zespołu Jeanne Gang. Wieżowiec usytuowany jest pomiędzy wysokimi zabudowaniami w ścisłym centrum Chicago, nad jeziorem Michigan, obok parku Milenium, przy North Columbus Drive. Od wschodu budynek graniczy z Lake Shore East Park.

Realizacja inwestycji rozpoczęta została na początku 2007 roku, na początku kryzysu na rynku nieruchomości, a budowę zakończono w roku 2010. W roku 2009 projekt zdobył nagrodę Emporis Skyscraper Award jako najlepszy wieżowiec pod względem wzornictwa i funkcjonalności.

Budynek został zaprojektowany w oparciu o program modelowania BEM. Interaktywny system jest złożony $\mathrm{z}$ ukierunkowanych przedmiotowo zbiorów skupionych na specyficznych aspektach przestrzennych projektu. Myślą przewodnią opracowania koncepcji budynku Aqua Tower (Rys. 6) było stworzenie budynku ekologicznego (np. optymalna ekspozycja w zimie i w lecie, ułatwiająca ogrzewanie pasywne), o oryginalnej formie, pełniącego funkcję hotelowo-mieszkalną, z wielofunkcyjnym kompleksem budowlanym, położonego na 28-hektarowej działce Lakeshore East (pomiędzy jeziorem Michigan i rzeką Chicago). Chicagowski wieżowiec został wyposażony w nieregularnie rozmieszczone balkony, tworzące „powłokę” pokrywającą prostopadłościenną bryłę główną. Zespół architektów z pracowni Studio Gang Architects przeprowadził analizę widoków z budynku i w jego kierunku z wielu punktów miasta (Rys. 7). Wyższe kondygnacje obejmują widok na jezioro Michigan oraz park Milenium, poniżej tych kondygnacji dostępny jest widok na park Harbor, kładkę dla pieszych BP w postaci żelbetowych ramp zakrzywionych w planie i rzeźbę „Cloud Gate” w parku Milenium.

Kształt elewacji wieżowca był modyfikowany w ten sposób, aby zapewnić najbardziej atrakcyjny widok zarówno z jego wnętrza, jak i na niego z ulic i otaczających placów i parków. Niewątpliwie było to wyjątkowe podejście architektów do wagi usytuowania tego typu obiektu w przestrzeni miejskiej, które umożliwiło uchwycenie wielu widoków nieosiągalnych z innych istniejących wieżowców.
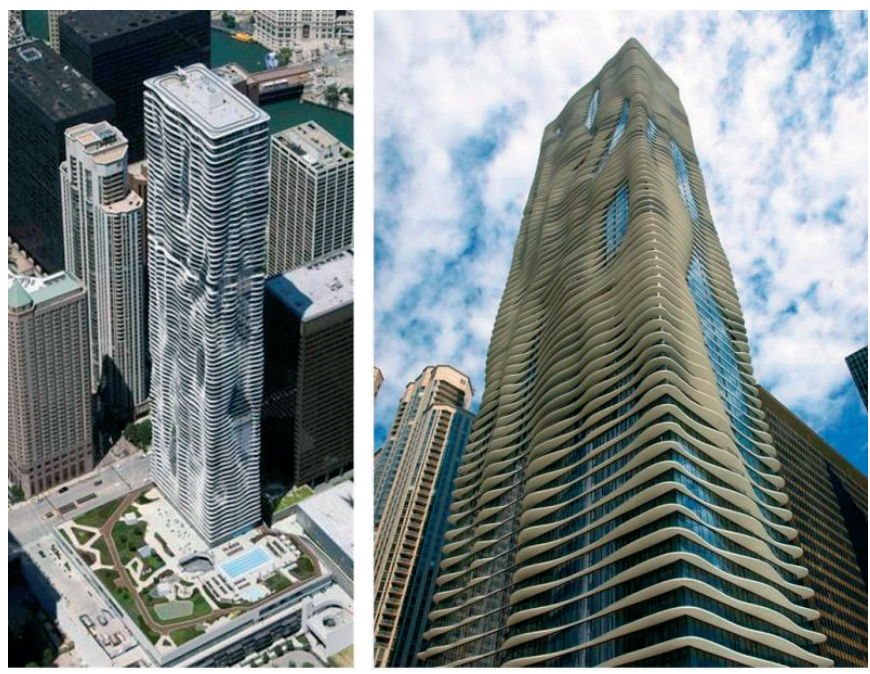

Rys. 6. Widok budynku Aqua Tower [10]

W mieście znanym z prostoliniowych wieżowców zaprojektowanych przez Van de Rohe, Gang wykorzystała krzywiznę owijając wieżę mieszkalną w sinusoidalnie falujące 
balkony (Rys. 8), przypominające falującą powierzchnię wody. Fale na powierzchni wieżowca nawiązują formą do prążkowanych skał wapiennych znajdujących się w sąsiedztwie jeziora Michigan, tworząc jednocześnie asymetryczne tarasy (Rys. 9). Tak jak fale na jeziorze, tak i powierzchnie każdego piętra z balkonami tworzą inną formę [9]. To sprawia, że konstrukcja budynku jest bardzo różnorodna i każdy taras ma inny kształt i wielkość. Oprócz rzeźbiarskiego charakteru fasady, system zewnętrznych balkonów spełnia także funkcję ekranu słonecznego, chroniącego wnętrze przed zbytnim nagrzewaniem się.

Budynkami, które poprzedzają krzywoliniową Aqua Tower w Chicago są cylindryczne bliźniacze budynki-ikony w Marina City zaprojektowane przez Bertranda Goldberga w 1964 roku (Rys. 2a). W budynkach tych rzuty pięter mają okrągły kształt, który wymusił na mieszkańcach dopasowanie mebli do pomieszczeń w kształcie klina.

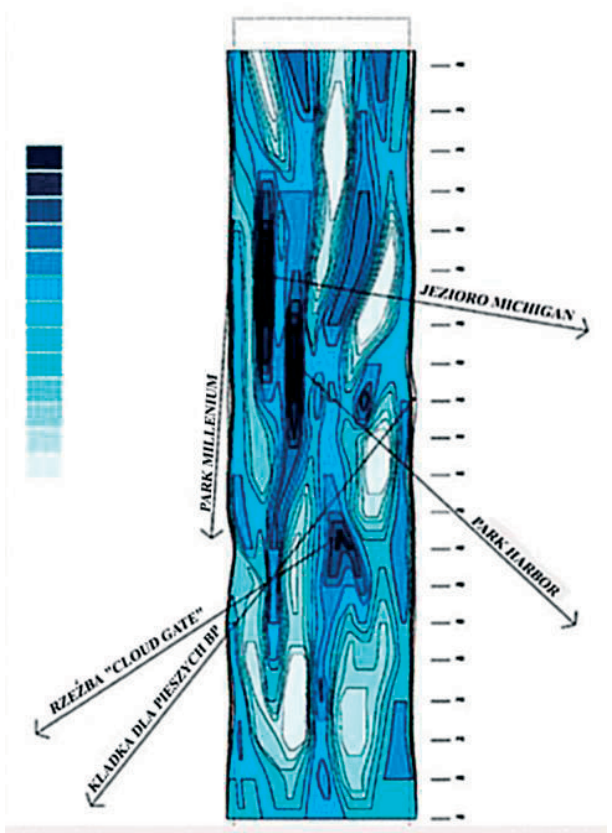

Rys. 7. Analiza możliwych widoków z budynku Aqua Tower (wśród nich z wyższych kondygnacji widok na jezioro Michigan oraz park Milenium, poniżej tych kondygnacji widok na park Harbor, kładkę dla pieszych BP i rzeźbę „Cloud Gate” w parku Milenium (Opracował J. Szołomicki)

Architekt James Loewenberg zdecydował się na konstrukcję żelbetową na rzucie prostokąta z centralnie usytuowanym trzonem budynku (Rys. 11). Na parterze przewidziano centrum handlowe, piętra od 4 do 18 zarezerwowano na hotel z 334 pokojami, piętra od 19 do 52 przeznaczono zaś na 474 mieszkania na wynajem oraz pozostałe piętra przeznaczono na 264 mieszkania lokatorskie, Penthousy zajmują 80 i 81 piętro [11]. Kilkukondygnacyjny garaż mieści 1557 miejsc parkingowych. Strefy komunikacyjne, mieszczące korytarze, klatki schodowe oraz windy, ulokowane są w centralnej części wieżowca. U postawy wieży znajduje się trójkondygnacyjne podium, obejmujące część hotelową. Na dachu tego podium, o powierzchni $7200 \mathrm{~m}^{2}$, zaprojektowano zielony taras, na którym zaplanowano odkryty basen, bieżnię do biegania oraz miejsce do uprawiania joggingu (Rys. 10). Na tym zielonym tarasie wiją się ścieżki pomiędzy niskimi wiecznie zielonymi roślinami i drzewami liściastymi, które nie są naturalne, ale tworzą obraz „geometrycznego naturalizmu”. 
Układ charakterystycznego konturu budynku powstał przy pomocy programu komputerowego. Zaszklenie podstawy zostało wykonane ze standardowych szklanych materiałów typu high-rise.

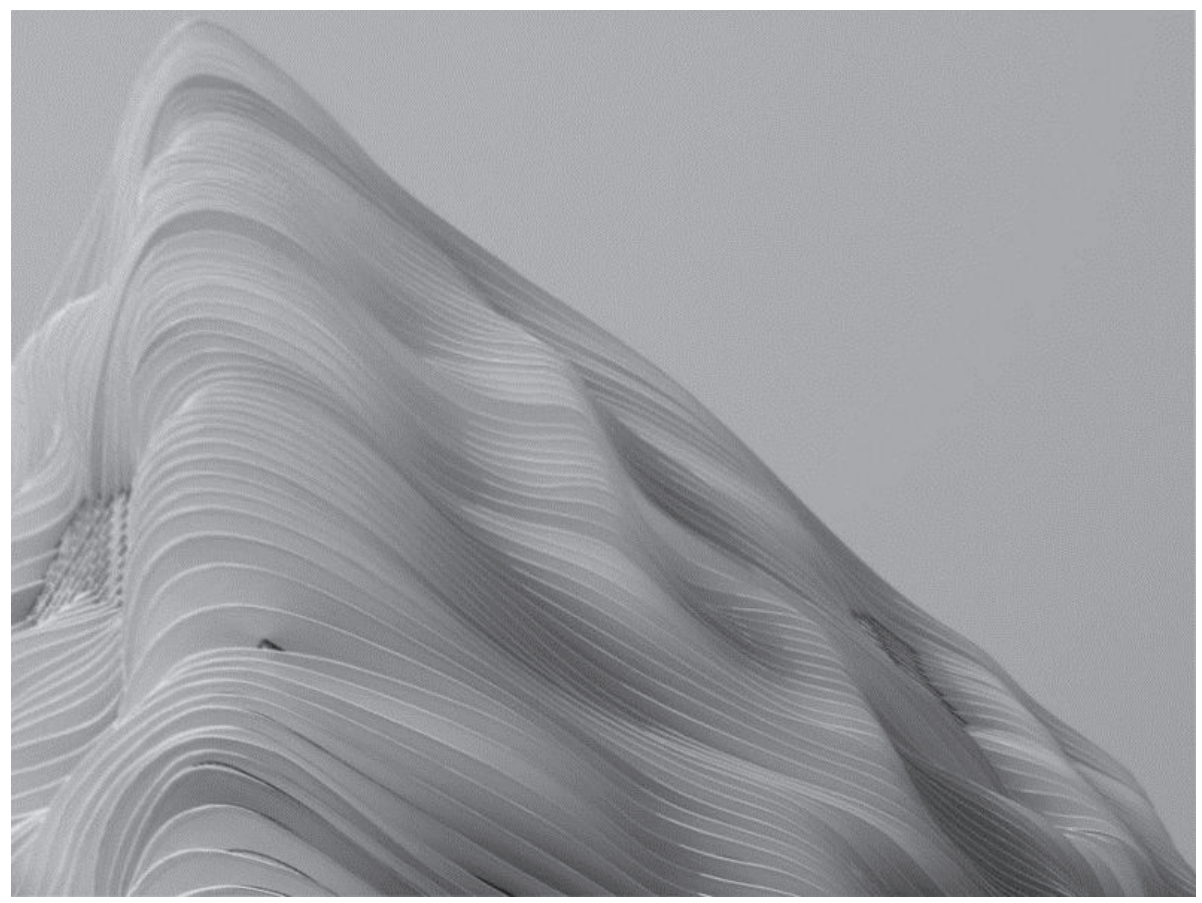

Rys. 8. Pofalowana fasada Aqua Tower, wykorzystująca system zewnętrznych balkonów (Opracował J. Szołomicki)

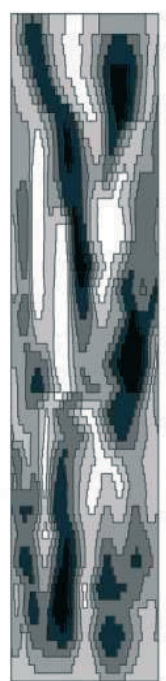

KONTURY

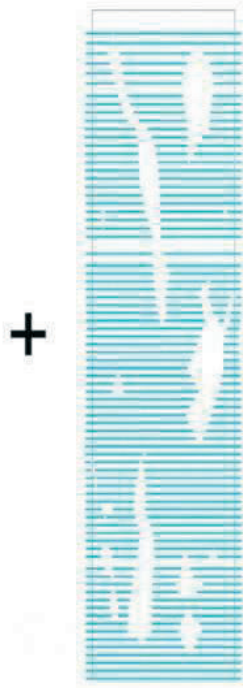

TARASY

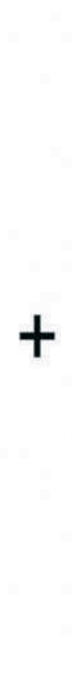

ROZLEWISKA

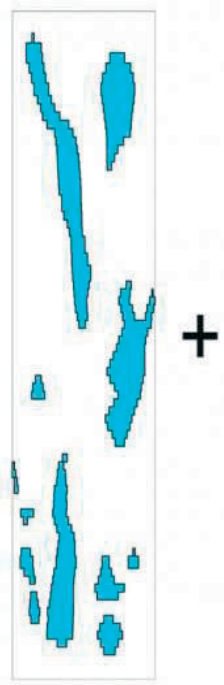

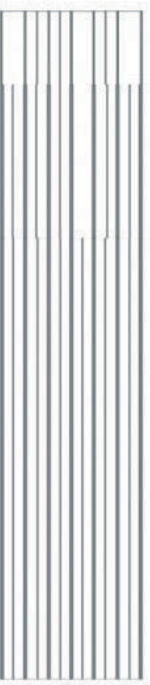

KOLUMNY

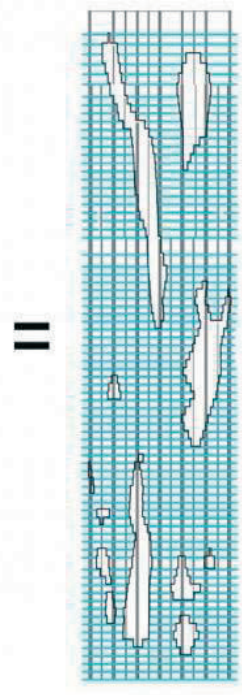

POLACZONY

Rys. 9. Schemat rozwoju elewacji Aqua Tower (Opracował J. Szołomicki) 


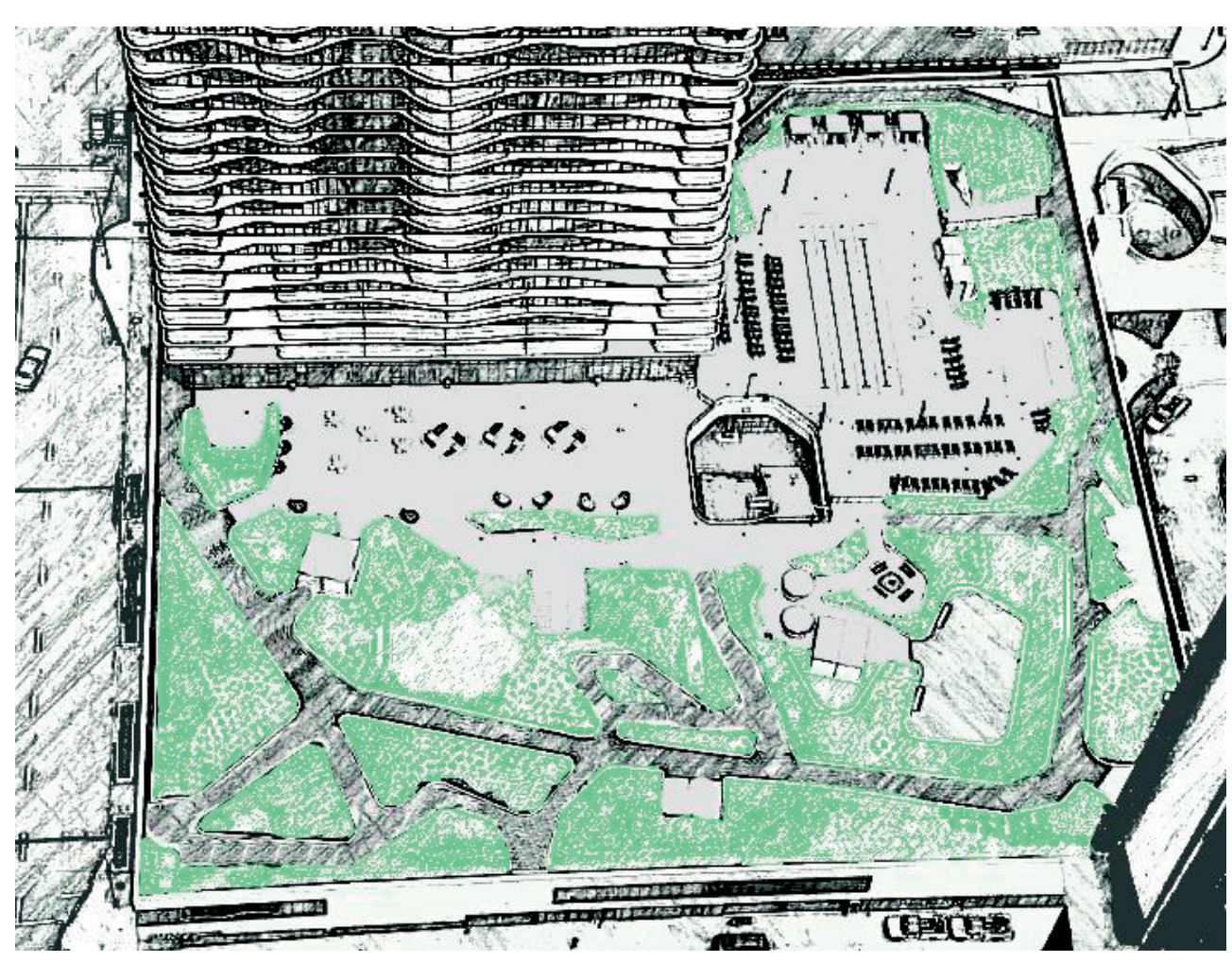

Rys. 10. Widok dachu podium, na którym zaprojektowano zielony taras, basen oraz bieżnię do biegania (Opracował J. Szołomicki)

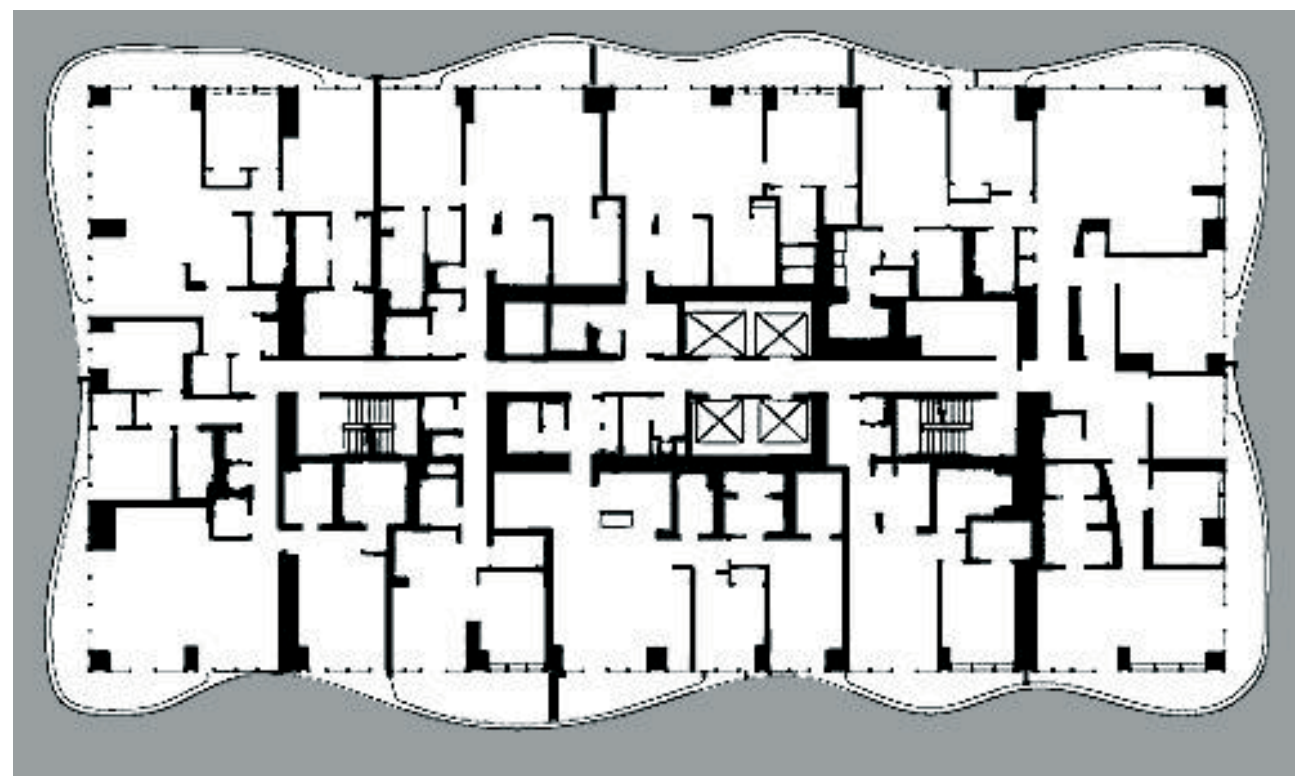

Rys. 11. Typowy rzut kondygnacji, centralnie usytuowany trzon budynku (Opracował J. Szołomicki) 


\subsection{Konstrukcja budynku}

Firma projektująca konstrukcję Aqua Tower (Magnusson Klemencic Associates) rozwinęła nowy, zoptymalizowany system konstrukcyjny. System ten łączył żelbetowy trzon umiejscowiony centralnie (Rys. 11,12), schodkowe betonowe ściany, ściany wysięgnikowe na poziomach 55 do 58 i 81 do 82 oraz ściany stężające na poziomie 57 . Ponadto zastosowano cztery różne wytrzymałości betonu dla trzonu i ścian nośnych. Strategicznie zlokalizowane ściany wysięgnikowe i stężające poszerzają bryłę budynku i wykorzystują zewnętrzne słupy w celu zapobieżenia kołysaniu. 87-kondygnacyjny Aqua Tower, o wysokości $262 \mathrm{~m}$ posadowiony jest na żelbetowej płycie fundamentowej, która ma grubość ponad $2 \mathrm{~m}$ i opiera się na 31 wierconych palach o średnicy dochodzącej do $3 \mathrm{~m}$ i zagłębionych do $30 \mathrm{~m}$ w podłoże dolomitowe. Siatka słupów w części podziemnej ma rozstaw 8,5 x 8,5 m. Sinusoidalne zakrzywienie płyt balkonowych na każdej kondygnacji przyjmuje różną konfigurację co powoduje, że wysunięcia balkonów, o grubości płyty $23 \mathrm{~cm}$, znajdują się w zakresie 0,6 do 3,5 m (Rys.13).

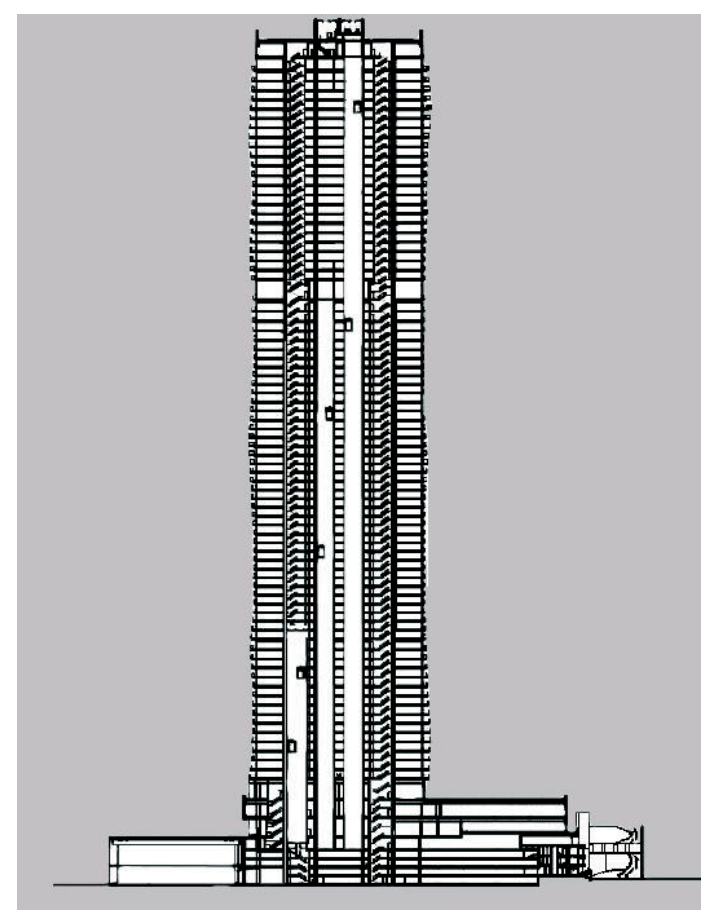

Rys. 12. Przekrój przez południową elewacje (Opracował J. Szołomicki)

Ten falujący charakter płyt balkonowych powoduje, że każda płyta ma inny kształt, co oznacza, że obliczenia statyczne były przeprowadzone dla każdej oddzielnie. Aqua Tower ma 78 indywidualnie zakrzywionych płyt stropowych ze wspornikowymi balkonami. Balkony są wykonane w technologii monolitycznej i w sposób ciągły są połączone z płytami stropowymi. Profil balkonów pomaga w odwodnieniu i utrzymaniem wody deszczowej poza fasadą budynku. Kilkanaście modeli komputerowych utworzono w celu analizy wytrzymałości i ugięcia tych unikatowych płyt stropowych na balkonach, których długość krawędzi przekracza 13 kilometrów. 


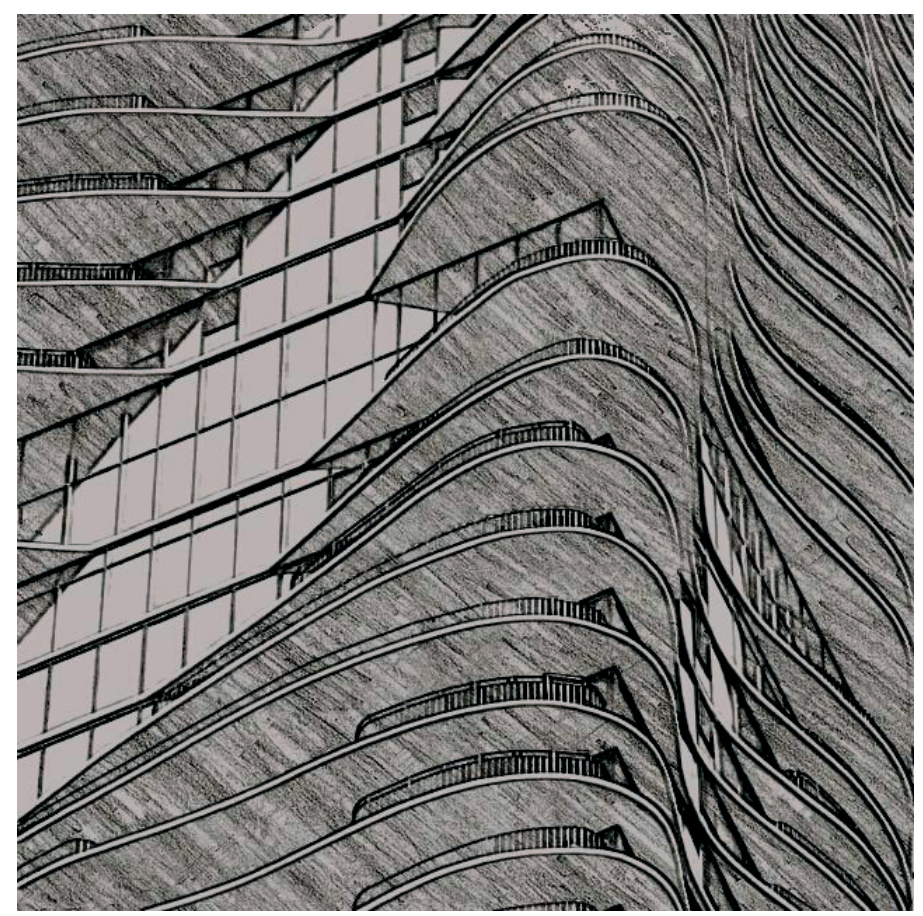

Rys. 13. Wysunięte balkony w Aqua Tower (Opracował J. Szołomicki)

\subsection{Aspekt energooszczędności i ekologii}

Budynek Aqua Tower jest zadziwiającym dziełem pokazującym jak można kreatywnie zastosować żelbet, aby uzyskać zarówno wybitną architekturę, jak i wytrzymałą konstrukcję. Orientacja budynku w kierunku wschodnio-zachodnim maksymalizuje ekspozycję w zimie, ułatwiając ogrzewanie pasywne (Rys. 14). Balkony na wschodniej fasadzie są celowo większe, żeby zredukować ekspozycję w lecie. Dodatkowo zastosowano niskoemisyjną powłokę we wszystkich przeszkleniach. Zespół projektowy Aqua Tower zamodelował sezonowe wzorce nasłonecznienia dla identyfikacji miejsc wymagających dodatkowego przeszklenia w celu zwiększenia charakterystyki energetycznej budynku. Przeszklenie na wschodniej i południowej fasadzie są wykonane ze szkła refleksyjnego bez zabezpieczenia balkonów, podczas gdy przeszklenie na zachodniej fasadzie mają zabarwioną powłokę, która zwiększa współczynnik zacienienia. Większość eksponowanego szkła jest spieczona, co nie tylko pomaga zredukować ciepło i odblaski, ale razem z ciemno szarą balustradą uniemożliwiają ptakom zderzenie $\mathrm{z}$ budynkiem.

W wieżowcu wykorzystano cały zestaw proekologicznych rozwiązań, do których należą między innymi system magazynowania wody deszczowej oraz energooszczędne oświetlenie.

Z budynkami wyposażonymi w systemy energooszczędne i proekologiczne kojarzą się obiekty posiadające w swoich elewacjach wprowadzone elementy zieleni, które niejednokrotnie kreują fasadę oraz przestrzeń wewnątrz budynku, umieszczona pomiędzy wyraźnie zaznaczonymi poziomymi podziałami elewacyjnymi sprawia wrażenie silnego sprzężenia, tak kontrastujących ze sobą betonu i zieleni. Roślinność znajdująca się na elewacjach ściśle współgra z elementami zieleni w przyziemiu otaczającym budynek. 


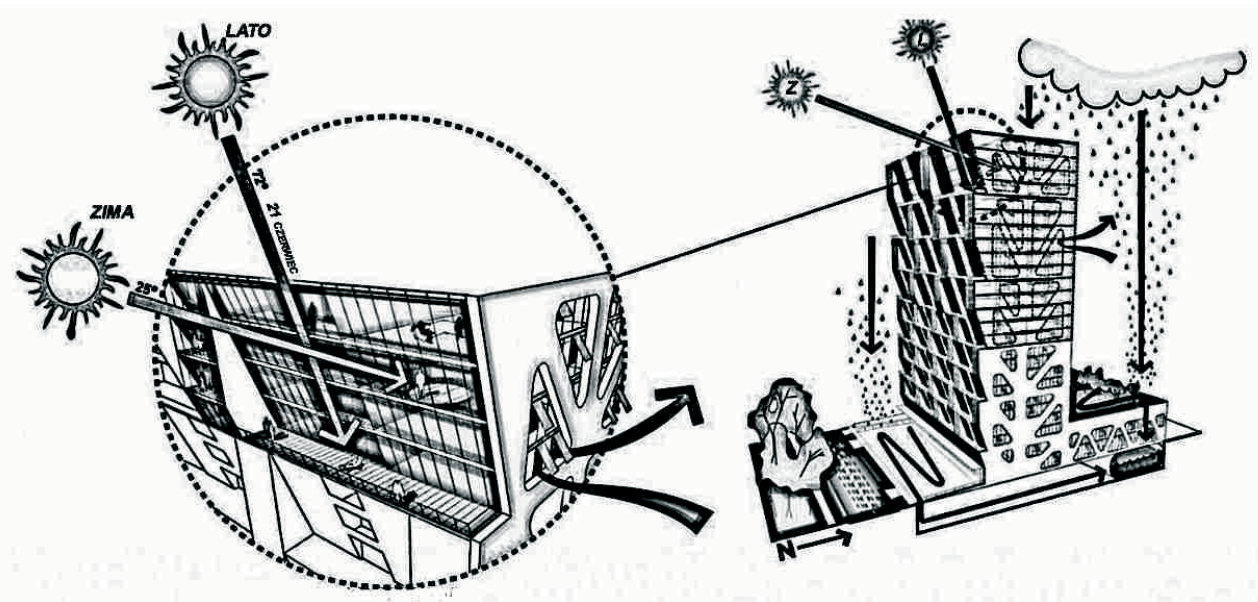

Rys. 14. Analiza orientacji budynku w celu uzyskania efektu maksymalizacji ekspozycji w zimie i minimalizacji w lecie (Opracował J. Szołomicki)

Zielony taras dachowy na trójkondygnacyjnym podium nie tylko daje efekt estetyczny, ale także pozwala obniżyć temperaturę otoczenia, poprzez zacienienie. Niestety, budynek ten trudno byłoby jednak zakwalifikować do budynków energooszczędnych. Do analizy energooszczędności budynku zastosowano pasywny, bezkontaktowy pomiar temperatury na powierzchni obiektu przy pomocy kamery termowizyjnej. Promieniowanie podczerwone zarejestrowane przez kamerę termowizyjną zostało przetworzone na kolorową mapę temperatur (termogram), która odzwierciedla rozkład temperatury powierzchniowej badanego obiektu. W wyniku przeprowadzonej analizy termogramów wykazano, że budynek emituje ciepło, które bezpowrotnie ulatuje w atmosferę. Występują tutaj liczne mostki termiczne na balkonach oraz dookoła okien (Rys. 17), spowodowane brakiem izolacji.
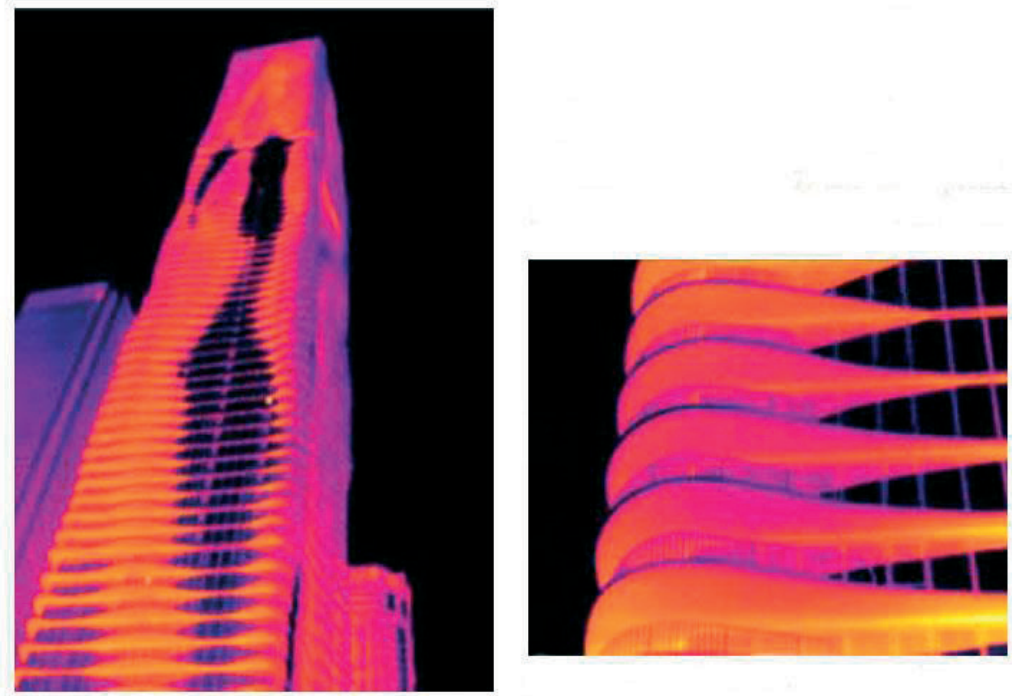

Rys. 15. Obraz Aqua Tower uzyskany z kamery termowizyjnej [12] 


\subsection{Oddziaływanie wiatru}

Jednym z największych wyzwań dla inżynierów projektujących współczesne budynki wysokie jest oddziaływanie wiatru. Ma ono charakter dynamiczny i jego siła zależy od właściwości aerodynamicznych budowli oraz porywistości wiatru.

Dla obiektów o skomplikowanych kształtach są wykonywane badania w tunelu aerodynamicznym [13], ponieważ nie ma procedur w normach dla tego typu obiektów (Rys. 16). Do przenoszenia obciążeń poziomych oraz aby zapobiec kołysaniu budynków, konstruuje się sztywne żelbetowe trzony umiejscowione w środku obiektów. Poza kołysaniem wiatr ma znaczący wpływ na budynek wtedy, kiedy częstość odrywania wirów zbliży się do jego częstości drgań własnych. Jeśli wiry wywołają drgania budynku równe jego częstotliwości rezonansowej, to mogą one wygenerować ogromne siły i spowodować katastrofę. Żeby temu zapobiec projektuje się aerodynamiczny kształt budynku albo budynek o bardzo zróżnicowanej elewacji, która uniemożliwia nakładanie się wirów. Innym sposobem przeciwdziałania oddziaływaniom wiatru jest strojony thumik masowy (absorber wibracji). Kiedy budynek zaczyna się kołysać w jedną stronę, wahadło z tą samą częstotliwością odchyla się w stronę przeciwną, tłumiąc wibrację, a tym samym zmniejszając odchylenia budynku. W innych typach strojonych tłumików masowych umieszcza się elementy hydrauliczne, które zamieniają energię kinetyczną w ciepło. Absorbery wibracji umieszcza się nie tylko w górnej części budynku lub na dachu, ale również w elementach konstrukcji, np. w stalowej kratownicy.

a)

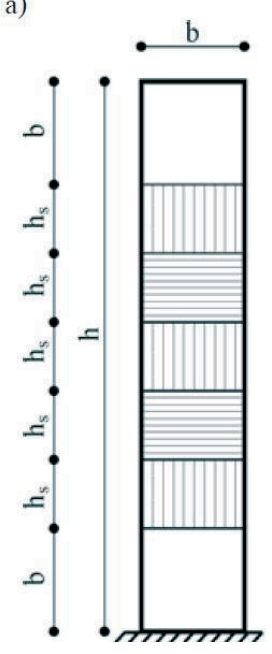

b)

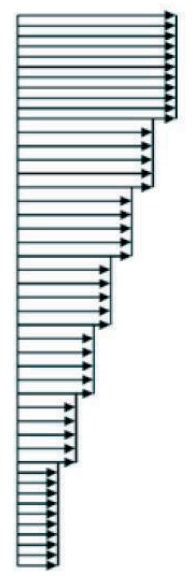

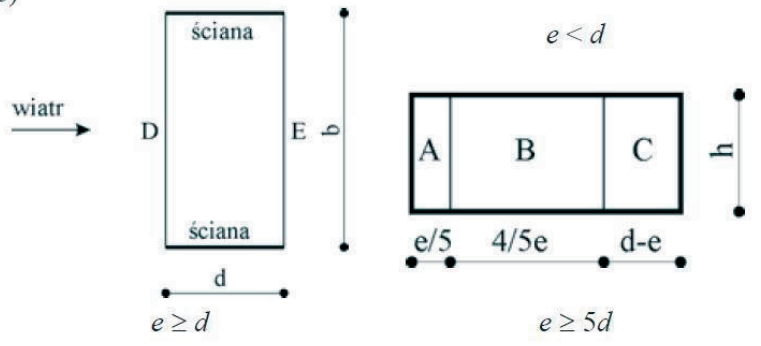

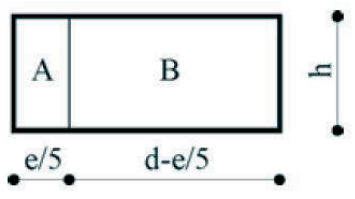

Rys. 16. Schemat przyjmowania obszarów obciążenia budynków wysokich: a) wzdłuż wysokości, b) na ścianie bocznej [14]

Aby nie zajmować cennej powierzchni użytkowej wieżowca pojawiły się pomysły innych rozwiązań problemu drgań. Christopoulos i Montgomery [15] stworzyli system, który rozkłada tłumienie w całym budynku używając wiskoelastycznego materiału lepkiego spojonego ze stalą. Ich thumik absorbuje drgania powstałe od wiatru lub trzęsienia ziemi i koncentruje uszkodzenia w poszczególnych partiach tłumika, które są łatwe do wymienienia

$\mathrm{W}$ fazie projektowania budynku wysokiego zaleca się przeprowadzać testy w tunelach aerodynamicznych. Tunele takie zaprojektowane są do symulacji zmian prędkości wiatru 
wraz ze wzrostem wysokości badanego modelu. Model poddany jest obciążeniu pod każdym możliwym kątem. Aby zobrazować efekt działania wiatru często używa się dymu. Czujniki zamontowane w różnych punktach modelu odczytują dane i po wprowadzeniu ich do komputera otrzymuje się szczegółową analizę.

W projektowaniu budynków wysokich takich jak Aqua Tower potrzebna jest wyjątkowa współpraca pomiędzy architektem i konstruktorem, żeby właściwie określić kształt budynku wraz z jego konstrukcyjnymi elementami. Właściwy kształt budynku ma przynieść korzyść w postaci zaburzenia formy oddziaływania wiatru wokół budynku do efektywnie zredukowanego wzbudzenia wiatrem. Różne aerodynamiczne modyfikacje bryły budynku mogą być podzielone na następujące grupy:

- stożkowaty przekrój poprzeczny i cofnięcie w linii zabudowania (Al Faisaliyah (Rys. 17a)),

- $\quad$ spiralny kształt (Avaz Twist Tower (Rys. 17b)),

- dodawanie otworów (Shanghai World Financial Center (Rys. 17c)),

- modyfikacja narożników (Tajpej 101 (Rys. 17d), Aqua Tower (Rys. 6)).

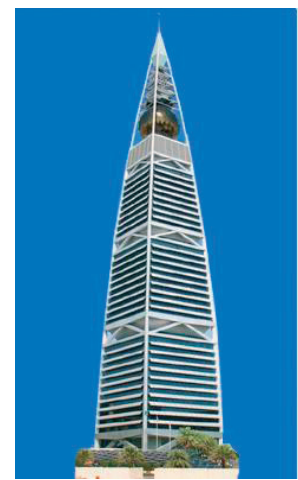

a)

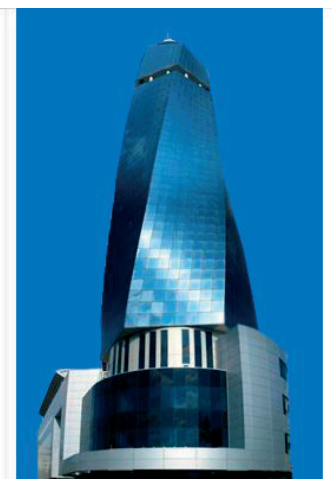

b)

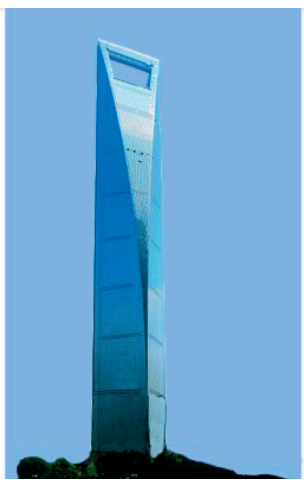

c)

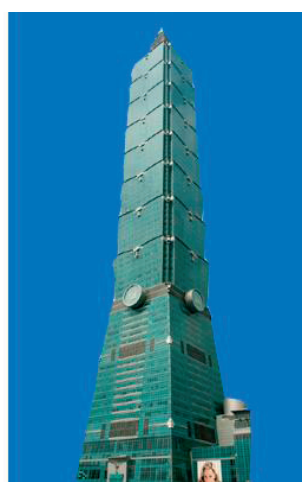

d)

Rys. 17. (a) Al Faisaliyah Complex, Rijad, Arabia Saudyjska (Foster\&Partners); (b) Avaz Twist Tower, Sarajewo (Faruk Kapidžić); (c) Shanghai World Financial Center, Szanghaj, Chiny (Kohn Pedersen\&Associates); (d) Tajpej 101, Taipej, Tajwan (C.Y. Lee \& Partners) (Opracował J. Szołomicki)

Z wszystkich możliwości modyfikacji narożników, zaokrąglenie krawędzi wykazuje najbardziej efektywne znaczenie dla udoskonalenia aerodynamicznych właściwości budynków wysokich przeciwko oddziaływaniu wiatru (badania doświadczalne przeprowadzone przez Kawai [16]).

W wyniku przeprowadzonych badań doświadczalnych [16] stwierdzono, że obciążenie wiatrem dla zaokrąglonych kształtów zostało zredukowane od 20 do 40 \% w porównaniu z rzutem budynku w kształcie kwadratu lub prostokąta. Zaprojektowany kształt budynku Aqua Tower znacząco zmniejsza jego podatność i niedostateczne tłumienie drgań charakterystyczne dla budynków wysokich spowodowane oddziaływaniem wiatru. Według projektantów, na początku uważano, że niezależny system thumienia będzie konieczny dla kontroli wzbudzenia wiatrem. Jednak po wyczerpujących analizach w tunelu aerodynamicznym stwierdzono, że zaokrąglona krawędź budynku w kształcie fali efektywnie zaburza opływowe oddziaływanie wiatru wokół wieży, redukując obciążenie wiatrem oraz eliminując potrzeby dodatkowego systemu thumienia. Dla tak wysokiego budynku zlokalizowanego w jednym z najbardziej wietrznych miast świata, brak dodatkowego systemu tłumienia na pewno jest ewenementem. 


\section{Podsumowanie}

Niewątpliwie o budynku Aqua Tower możemy powiedzieć, że jest dziełem architektonicznym, w którym forma odgrywa najistotniejszą rolę. Dla osiągnięcia tej wspaniałej formy i, co się z nią bezpośrednio wiąże, konstrukcji, wykorzystano współczesną technologię komputerową w postaci oprogramowania BEM. Analizę statyczną i wymiarowanie płyt stropowych, płyt balkonowych i fundamentów wykonano za pomocą programu SAFE. Natomiast analizę geometryczną fasady budynku przeprowadzono programem Grasshopper.

Podstawowym zagadnieniem podczas projektowania było stworzenie takiej geometrii, która zredukuje opływowe oddziaływanie wiatru do akceptowalnego poziomu. Projektując ten budynek wykorzystano krzywiznę owijając wieżę mieszkalną w sinusoidalnie falujące balkony, co spowodowało, że powierzchnie każdego pietra tworzą inną formę.

Niestety, pomimo wielu rozwiązań energooszczędnych popełniono błędy polegające na braku zastosowania izolacji na balkonach i dookoła okien. Prawdopodobnie wiąże się to z nieprzywiązywaniem szczególnej wagi do problemu strat cieplnych w USA.

\section{Literatura:}

1. Jasiński A. Znaczenie budynków wysokich $i$ wysokościowych we wspótczesnej urbanistyce. Przestrzeń i Forma, 2010.

2. Rola P., Ryznar P., Stachura K. Powłokowy - prętowy budynek wysoki - wieża. Praca dyplomowa magisterska, Politechnika Świętokrzyska, Wydział Budownictwa i Inżynierii Środowiska, 2012.

3. The Skyscraper Center, The Global Tall Building Database of the CTBUCH.

4. Nassery F. Formy geometryczne w architekturze wspótczesnej. Biblioteka cyfrowa Politechniki Krakowskiej.

5. Rychter Z. Wplyw ksztaltu wieżowców na jakość konstrukcji. Architecturae et Artibus, 2/2013.

6. Vahedi A. Nature as a source of inspiration of architectural conceptual design. Diploma Thesis, Eastern Mediterranean University, Gazimağusa, North Cyprus, 2009.

7. Vollers K. Morphological scheme of second-generation non-orthogonal high-rises. Proceedings of CTBUCH 8th World Congress, Dubai, 2008.

8. Gang J. Three points of residential high rise. Designing for social connectivity. CTBUCH Research Paper, 2015.

9. Zacks S. The art of nesting. Metropolis Magazine, June 2008.

10. CTBUCH - The Global Tall Building Database. Skyscraper center.

11. Stephens S. Aqua Tower. www.chicagoarchitecture.info/Building/913/Aqua.php.

12. Lstiburek J., Fellow A. The truth is out there: efficiency and iconic architecture can co-exist, Journal of Building Enclosure Design, 2013.

13. Lipecki T. Oddziaływanie wiatru na budynki wysokie w świetle badań własnych i ujęć normowych. Budownictwo Architektura 12(2), 2013.

14. EC1:PN-EN 1991-1-1 Actions on structures - Part 1-1: General actions - Densities, selfweight, imposed loads for buildings.

15. Montgomery M., Christopoulos C. Experimental validation of viscoelastic coupling dampers for enhanced dynamic performance of high-rise buildings, Journal of Structural Engineering 2015.

16. Kawai H. Effect of corner modifications on aeroelastic instabilities of tall buildings, Journal of Wind Engineering and Industrial Aerodynamics 43(3) (1998). 


\title{
Aqua Tower in Chicago \\ - non-energy efficient ecological skyscraper (icon of modernist architecture)
}

\author{
Jerzy Szołomicki, Piotr Berkowski
}

Division of Building Physics and Computational Design Methods,
Faculty of Civil Engineering, Wroclaw University of Technology,
e-mail: jerzy.szolomicki@pwr.edu.pl, piotr.berkowski@pwr.edu.pl

\begin{abstract}
The aim of the paper is to present and analyze the ecological skyscraper Aqua Tower, icon of modernist architecture. The main idea of development of Aqua Tower concept was creation of ecological building with original architecture used for residential and hotel purposes. Chicago skyscraper is equipped with irregularly spaced balconies forming a "shell" which cover the main orthogonal core structure. Designed shape of the building significantly reduces its vulnerability and inadequate damping of vibrations caused by the impact of the wind which is typical for high-rise buildings. In the first part of the paper various geometric forms of modern high-rise buildings are analyzed. Subsequently was characterized Aqua Tower skyscraper in terms of architecture and design, taking into account the effect of wind and aspect of ecology and energy efficiency. The Aqua Tower building is an amazing masterpiece that shows how concrete can be creatively used to get outstanding architecture and extremely strength construction. The whole set of environmental solutions which include, among other things, a system of rainwater storage and energy efficient lighting was employed. Green vegetation placed between the horizontal divisions clearly marked façade and gives the impression of strong coupling, so contrasting are concrete and greenery. Greene roof terrace on the three-floor podium creates an image of "geometric naturalism", which not only gives aesthetic effect, but also lowers the ambient temperature.
\end{abstract}

Keywords: Aqua Tower; high-rise buildings, geometrical forms, ecology. 
